\title{
An examination of the challenges of quality water provision in Madibeng local municipality, North West province
}

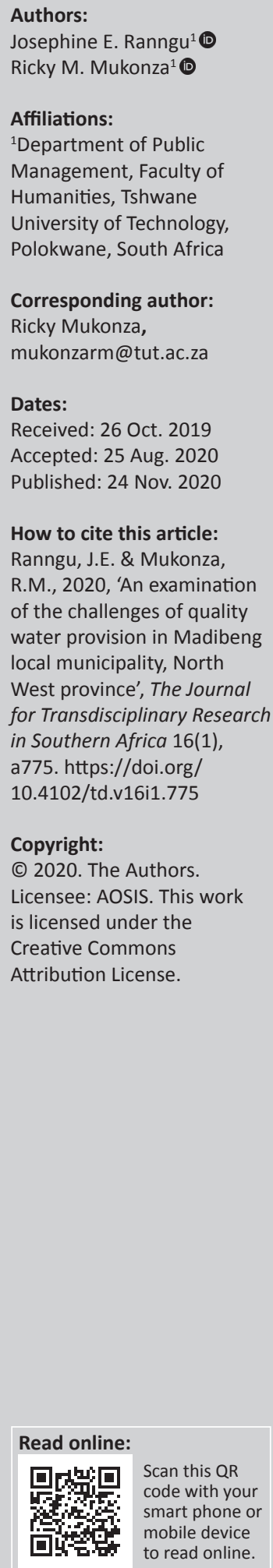

\begin{abstract}
Like most municipalities in South Africa, Madibeng local municipality (MLM) is faced with the dual problem of access to water and provision of quality water services. Despite the constitutional responsibility bestowed on municipalities to ensure that residents have consistent access to affordable, reliable and quality water, communities in larger portions of the MLM still have no access to quality water services. This article aimed to explore challenges of quality water service provision in MLM. Focusing on the Letlhabile area within the MLM, the article applied a mixedmethod research approach whereby a non-probability sampling design was used to draw a sample of 70 respondents, comprising residents and responsible municipal officials. As part of the study findings, several challenges hindering provision of water services in MLM were confirmed. These included faltering district-local relations between MLM and Bojanala Platinum District Municipality, acute scarcity of technical skills such as water treatment technicians and as paucity of competent municipal leadership. In its conclusion, this article proposes possible solutions to the water-related problems prevalent in the municipality.
\end{abstract}

Keywords: Madibeng local municipality; water; service delivery; challenges; provision; quality water.

\section{Introduction}

Madibeng local municipality (MLM) has a faltering water service delivery system, which led to healthcare hazards for its inhabitants as recently as 2016 (Govender 2016:9). For instance, the provision of contaminated water to the residents of Letlhabile in Brits led to service delivery protests in the area in 2017 (Municipal IQ 2017). According to Govender (2016), such protests are an indication that the municipality is failing, both in terms of access and quality of services delivered to its people. Therefore, such failures inherently implicate health conditions for members of the public, thereby promoting inconsistency, in so far as sustainable development is concerned. This article looks at service delivery from two perspectives: general access to services by the communities and the quality of those services. Cognisance is taken of the solid link between service access or quality and the ability of citizens or residents to lead decent lives. Oftentimes, however, municipalities experience difficulties in providing such public services (Akinboade, Mokwena \& Kinfack 2014:5; Rogerson 2018:23). These services include, inter alia, the inability to provide adequate and clean water to their communities - and MLM is not an exception. Whilst the right to water is engraved vividly in various policies and statutes such as Section 27 of the Constitution (Republic of South Africa [RSA] 1996) ensuring that communities sustainably get access to safe, clean and sufficient amounts of water goes beyond a mere inscription in black and white. A case in point is the MLM, which has struggled to implement and reach its service delivery targets for 5 years in a row, due to scarce resources and poor limited capacity (South African Human Rights Commission [SAHRC] 2016:1). Based on this, it is crucial to highlight the fact that the failure by the said municipality to provide water services sustainably to its residents violates their right to such services and further affects their ability to have a decent standard of living. In addition, this is taking place almost 25 years after the dawn of democracy, thereby putting the need to exploit the gains of freedom in jeopardy. The overall objective of this article has been to examine the challenges to quality water provision in MLM, in the North West province of South Africa. The following questions were asked: What are the statutory and policy prescripts of water provision, challenges to water provision and theoretical approaches guiding water service provision on the local government sphere of South Africa? Are there monitoring arrangements for water (and sanitation) provision in MLM? And lastly, to what extent is MLM complying with quality water provision and regulations policies? The research methodology chosen for the study 
is also presented. Presentation and analysis of the empirical findings are done. Lastly, the preceding evidence and analyses, conclusion and recommendation are presented.

\section{Contextualisation of the study location - Letlhabile}

MLM has 43 villages (MLM Integrated Development Plan 2015-2016), with a total population of 536110 as of the 2016 population census, the study area (Letlhabile) has a total population of 41497 residents (City Population 2017:2). Although this represents about $8 \%$ of the total population of the municipality, the study regards this is as relevant because these are the places that have been highlighted with water service delivery challenges.
Figure 1 is a map depicting the areas that the study focused on. The following section reviews literature on the subject matter.

\section{Literature review}

South African water service delivery is characterised by both achievements and challenges. There are several challenges that exist to effectively supply affordable, sufficient, clean and safe water to communities in South Africa. These include a lack of attention to maintenance and sustainability, as well as uncertainty about the government's ability to sustain current funding levels in the water sector (Brillantes \& Cuachon 2002). Such impediments are seen to be markedly affecting how communities in MLM access water and get

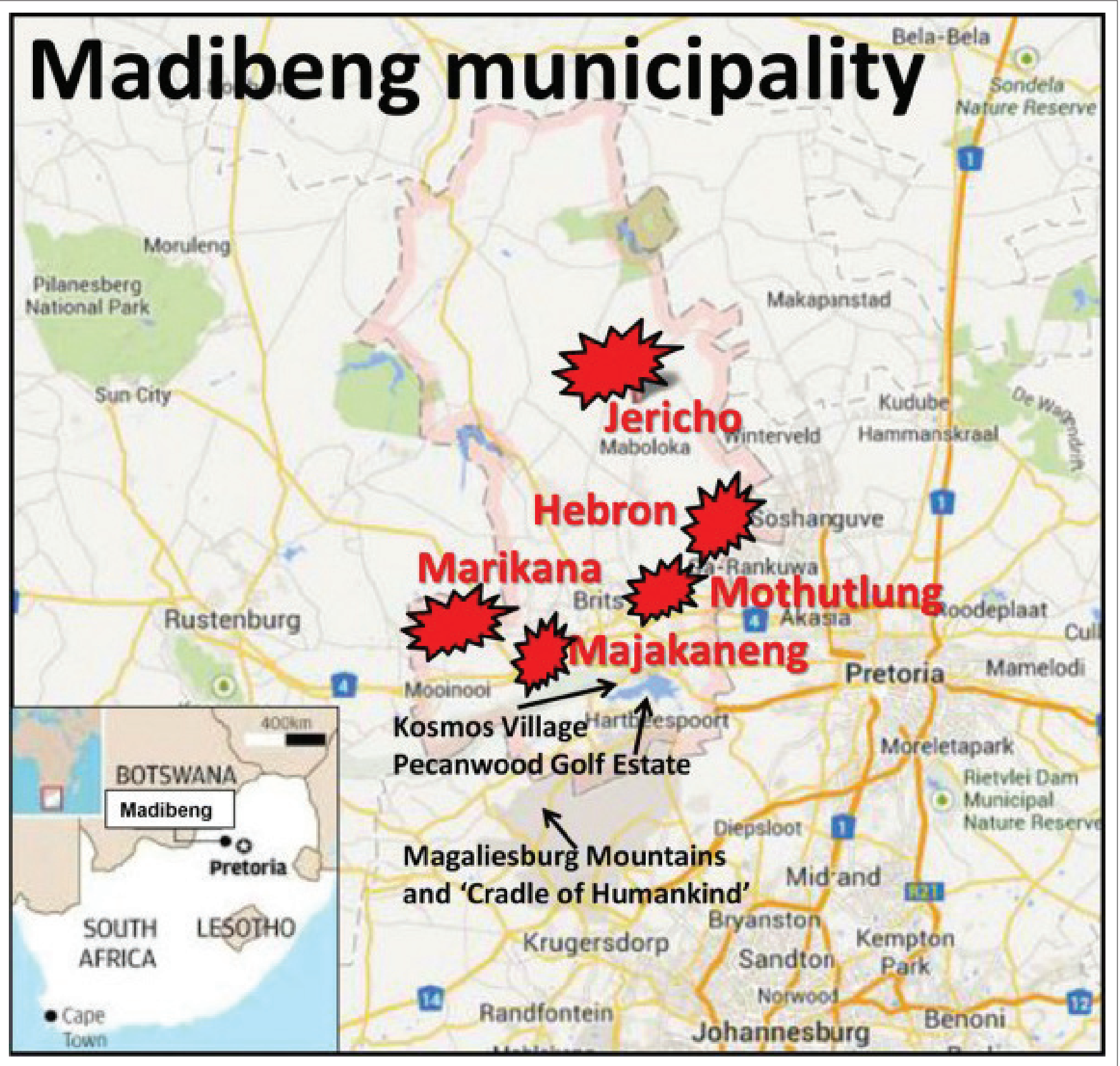

Source: Bond, P., 2014, South Africa's resource curses and growing social resistance, viewed 10 July 2020, from https://monthlyreview.org/2014/04/01/south-africas-resource-curses-growingsocial-resistance/

FIGURE 1: Madibeng municipality. 
proper quality in rendered water. Whilst it may be easy to cast blame on municipalities and related role-players, there is considerable difficulty in ensuring that communities get quality water. According to Moeti and Khalo (2008:222), the issue of balancing the costs of providing water with the tariff (price) that consumers should pay for receiving it could be a key challenge in the provision of water to local communities. It is further acknowledged that there are some communities that are so impoverished that they cannot afford to pay any tariff on delivered water. In such scenarios, it was found that most municipalities relied on revenue generation strategies, as well as goodwill from civic and community-based organisations, to foot the bill for treating and providing quality water. It is also recognised that constrained service delivery progress results in a shortage of service delivery capacity (Khalo 2008:228).

Mafete (2005:45) observes that the delivery of safe and sufficient water remains a goal of the local sphere of government in the 21st century. As such, in order to counter the relentless water problems, the author stressed a need to launch awareness campaigns for those who are able to pay for water services in time to avoid local government swindling people; to have improved staff training and development; to have community involvement in the process of water delivery; and to sub-contract some tasks to other multi-sectoral stakeholders (Mafete 2005). Kolanisi (2005) concurred, adding that there is a need for the delivery of quality water to communities and that one should also consider the demand and use of water to enable those providing water to deliver it sufficiently to the communities. In addition, there is a need for an all-inclusive, multiplestakeholder approach to service delivery, to ensure that all relevant role-players collaborate in the sustainable delivery of water to local communities. From another angle, the perceptions and service expectations of water consumers should be the starting point for the delivery of this important community need (Kolanisi 2005).

Hofmeyr (2012:110) regards the existence of poor water service delivery in local government as a sign of a dismal failure of intergovernmental cooperation and relations. Smooth intergovernmental relations should enable the easy detection of failing quality water provision, which could trigger provincial intervention in the form of Section 139 of the Constitution (RSA 1996), which authoritatively states that:

\footnotetext{
... when a municipality cannot or does not fulfil an executive obligation in terms of the Constitution or legislation, the relevant provincial executive may intervene by taking any appropriate steps to ensure fulfilment of that obligation. (p. 1)
}

Such interventions are warranted, when municipalities fail to deliver basic services, like water or sanitation. For Hofmeyr (2012), upholding the spirit of 'oneness in separation' across the three spheres of government in South Africa could make way for the successful delivery of critical municipal basic services.

Khan (2003) explored the prospects of privatising water service delivery in South Africa as a way of improving the efficiency of service delivery. In the main, Khan (2003:78) mentioned that the privatisation or quasi-privatisation of an essential service, such as water, will have a detrimental effect for the poor or low-income earners, who sometimes cannot even afford to pay for low-priced government water tariffs. Given the prevalence of a culture of non-payment in South Africa, Khan (2003) argues that private-sector water providers would never dare to provide water in deep-lying rural areas, where they may expect to have a huge proportion of water tariff defaulters. Khan (2003:78) further suggests that public services need not get sub-contracted to profit-obsessed, private-sector companies, who only seek to maximise profits without paying much attention to the need to ensure basic, decent living standards to the citizenry. Hence, water should always be overseen, or provided, by a government through a working social contract.

Makhari (2016), who assessed water service delivery in three metropoles, namely, City of Cape Town, City of Tshwane and EThekwini, concluded that water service delivery could be made easier by keeping and monitoring water service management records or indicators. Furthermore, periodic monitoring and punitive evaluation of a municipality's water server provision plan is crucial in keeping local government on track with its targets on improving both access to water and quality of delivered water (Makhari 2016:61). In the metros sampled (Cape Town, Tshwane and EThekwini), the study recommended the improvement of water governance through competent leadership and staff, together with the balancing of expenditure and delivery to build financial sustainability. Above all, water services are a major community need and should, therefore, be delivered in an economic, efficient and effective manner (Makhari 2016).

Lastly, a study by Madi (2016) on the delivery of equitable water and sanitation services in Newcastle Local Municipality revealed that, although there was water service delivery to the community, this was not equitable, with some (mostly informal settlements) having to use pit latrines for ablution. In addition, there were water cuts, leading to erratic water supply, especially in areas with low-income earners. The major findings by Madi (2016:86) were that politicians were out of touch with the realities, when it came to the water and sanitation needs of Newcastle Local Municipality; and technically skilled employees were in short supply, disrupting water and sanitation service delivery. In the end, Madi (2016) values the training of municipal employees responsible for water treatment and delivery; the installation of yard taps in communities, which use common open-space taps, because these taps are currently vulnerable to vandalism and negligence; and the expansion of water and sewage treatment plants to enhance access to water and sanitation.

In light of the above, the perused literature touched on different aspects of water service delivery in the local sphere of government; however, none of them focused on the quality of water delivered, especially in the context of MLM. This is a municipality, which has, over the past 5 years, been on a collision course with its residents on its failure to deliver 
water in a sustainable manner (Municipal IQ 2017). A myriad of factors have been imputed to the municipality's failure to ensure that both improved access and good quality water services are established and sustained. In addition, the study further identified a gap which exists in reviewed literature where no single study focused on water access, quality and monitoring of water service delivery.

\section{Water provision in local government: Legis/ative overview}

South Africa has a quasi-federal system of government, with one national government, nine provincial government entities and 259 municipalities constituting local government (Municipalities of South Africa 2018:1; Republic of South Africa 1996:21). Although various legislative and regulatory frameworks place water service provision as the responsibility of local government, national and provincial governments are mandated by Schedule 4 (Part B) of the Constitution of South Africa (RSA 1996) to perform oversight in the sustainable provision of water (Haigh et al. 2008:15). Therefore, water is the responsibility of municipalities, which should do so in line with provincial and national water service delivery blueprints. Section 27 (1) (b) of the Constitution (1996) further outlined the right of everyone to access sufficient food and water.

In the same vein, the White Paper on Local Government (RSA 1998a) obligates municipalities to create liveable societies and communities through, amongst others, provision of accessible and safe drinking water. How municipalities execute their roles and responsibilities is mandated in the guide provided in the objects of local government in Section 154 of the Constitution (1996). Of particular importance to the article is Section 152 (a) (b) of the Constitution (1996), which states that one of the objectives of local government is 'to ensure the provision of services to communities in a sustainable manner'. In deducing this, the article values the central role that municipalities have in bringing social and economic development to communities. Recent semantic developments have seen local government in South Africa labelled by scholars, such as Nsingo and Kuye (2005:755), as well as Nealer and Raga (2007:180), as 'grassroots' government, due to its proximity to the people and its goal of democratising government. Furthermore, there is a moral and inherent mandate that the State should fulfil in the process.

Section 27(2) of the Constitution (1996) declares that the state should take appropriate legislative and other measures to ensure a progressive realisation of the citizens' rights, including the right to access water. In this regard, various legal and policy frameworks have been passed to ensure citizens have unhindered access to clean, drinkable water. Local statutes such as Municipal Systems Act (32 of 2000) empower municipalities to raise revenues to fund their services. Hence, municipalities get their funding from taxes, rates and charges, amongst others; thus, such revenue is accumulated from members of the public. In return, residents participate in local elections and pay taxes, where applicable, in anticipation of service delivery. Section 155 (1) of the Constitution of the Republic South Africa (1996) provides for the placing of South Africa's municipalities into three categories, as a way of streamlining their operations and abilities to fulfil their service delivery mandates. In that regard, the following categories exist in local government:

- Category A, comprising those municipalities that have exclusive municipal executive and legislative authority in their areas of jurisdiction. These types are commonly referred to as metropolitan municipalities. This category currently has eight municipalities.

- Category B, consisting of municipalities that share municipal executive and legislative authority in their areas with a Category $\mathrm{C}$ municipality within whose area they fall. These are commonly called local municipalities, and there are 207, as of 2016.

- Category C is comprised of those municipalities, which have municipal executive and legislative authority in an area that includes more than one municipality. Often referred to as district municipalities; there are 44 district municipalities.

In light of this, MLM falls within Category B and, hence, is called a local municipality, because it shares municipal executive and legislative authority with a district municipality - in this case, Bonajala Platinum District Municipality. This status accords the local municipality the authority to determine its own legislative and executive powers in a bid to further its mandate of service delivery (Shopola \& Mukonza 2020). The municipality also is empowered to determine its own ways of delivering quality water to residents, and this should be in line with its district's vision and mission. This article thus values the need for intergovernmental cooperation in the delivery of services. This is also echoed by the White paper on local government (RSA 1998a), which encourages district-wide planning and planning alignment between municipalities sharing the district jurisdiction. In the ensuing paragraph, the article unpacks the legal mandate of local government. In addition, Chapter 7 of the Constitution (1996) is exclusively dedicated to the objectives of local government in South Africa. However, of particular interest to this article is Section 152(1), which stipulates that the objectives of local government are to

- provide democratic and accountable government for local communities;

- ensure the provision of services to communities in a sustainable manner;

- promote social and economic development;

- promote a safe and healthy environment; and

- encourage the involvement of communities and community organisations in matters of local government.

These objectives could also enable municipalities to move progressively towards the social and economic enhancement of local communities. In this regard, the ideal of these objectives of local government may seek to provide the core principles, mechanisms and processes that could be necessary 
in local government. Take, for example, the aims linked to service delivery that reflect on the need for service provision, socio-economic development and health and safety. It is this collective obligation that municipalities, such as MLM, are given for their local communities. The current study values the great bearing that Section 152 (1) of the Constitution of the Republic of South Africa (1996) has on the need for quality water in municipalities such as MLM.

\section{Research methodology: Approach, data collection, sampling methods and respondents' profile}

This article adopted a mixed-methods approach, which, according to Creswell and Plano Clark (2011), is a mixture or triangulation of both qualitative and quantitative research methods. Importantly, a key assumption of this approach is that both qualitative and quantitative data provide different types of information, often detailed views of participants qualitatively and scores on instruments quantitatively, and together they yield results that should be the same (Creswell \& Plano Clark 2011). As guided by Brynard, Harnekom and Brynard (2014), empirical data were collected using both closed-ended questionnaires and interview techniques which were then analysed thematically and triangulated with the secondary data sourced from the existing literature, thereby strengthening validity. In terms of selecting the respondents, the study used a nonprobability sampling method that, according to Bless, Higson and Kagee (2006), is commendable when the target population is relatively small and accessible. Table 1 presents the total number of respondents in this study.

Whilst this study used a mixed-method approach that was skewed towards the qualitative research paradigm, the research questions were equally spread across both the questionnaire and interview schedule.

\section{Presentation and discussion of findings}

This section presents, analyses and discusses the data and findings gathered through the questionnaire and interviews, in line with the following three study goals:

- Ascertain if there is monitoring of water (and sanitation) provision in MLM.
- Assess the extent to which MLM is compliant with water provision and regulation policies.

- Establish the challenges confronting MLM in the provision of quality water to its residents.

Also in this section, the analysis is premised on the quality water provision specifics from the data collected through the questionnaire. Briefly, these specifics regard access, quality, compliance and monitoring for efficient and effective delivery of water in MLM.

\section{Access to water}

Resident respondents were asked various questions relating to their access to quality water in their locality. The questions also explored the relative distances that some residents of MLM had to walk to fetch water for domestic use and drinking. The data shown in the frequency distribution in Table 2 reflect the dire need to improve access to safe drinking water in MLM.

\section{Quality of water delivered}

Letlhabile (near Brits) is one of the areas that have suffered immensely in the faltering water provision culture in MLM. A case in point is the delivery of contaminated water through tankers; the water was so dirty and contaminated that residents could not use it for any personal or domestic purposes. Water quality becomes an issue, because contaminated water can contain harmful pathogens, which cause and aggravate the outbreak of water-borne diseases, like cholera, dysentery and typhoid. Because Section 27 of the Constitution (RSA 1996), and other global statutes declared water a fundamental human right, this level of access to water for the residents of MLM constitutes an infringement of citizens' rights. Thus, the government has to take appropriate remedial action to correct such a situation. The data are presented in Figure 2.

Figure 2 reflects positive results in relation to the quality of water delivered in the Letlhabile area, but at the same time it

TABLE 2: Frequency distribution of residents' access to water.

\begin{tabular}{lcc}
\hline Access to water & Frequency & Sample (\%) \\
\hline Yes-always & 32 & 58 \\
Yes-sometimes & 10 & 18 \\
No-not at all & 13 & 24 \\
\hline Totals & $\mathbf{5 5}$ & $\mathbf{1 0 0}$ \\
\hline
\end{tabular}

TABLE 1: Respondents' profiles $(n=70)$.

\begin{tabular}{|c|c|c|c|c|c|}
\hline \multirow[t]{2}{*}{ Respondent category } & \multirow[t]{2}{*}{ Area of origin } & \multirow[t]{2}{*}{ Data collection method } & \multicolumn{2}{|c|}{ Gender } & \multirow[t]{2}{*}{ Totals } \\
\hline & & & Male & Female & \\
\hline \multicolumn{6}{|l|}{ Sample 1 (simple random sampling method) } \\
\hline \multicolumn{6}{|l|}{ Sample 2 (purposive judgemental) } \\
\hline Madibeng Municipal Officials & Madibeng Municipal Headquarters & Key Informant Interviews & 3 & 5 & 8 \\
\hline Bojanala Platinum District Municipal Officials & District Municipal Headquarters & Key Informant Interviews & 1 & 1 & 2 \\
\hline Civic Organisations Officials & $\begin{array}{l}\text { Letlhabile; Brits; Mothotlung West; } \\
\text { Hartbeespoort; Elandsrand; and two rural villages }\end{array}$ & Key Informant Interviews & 2 & 3 & 5 \\
\hline Sample percentage (\%) & - & - & 37 & 63 & 100 \\
\hline
\end{tabular}




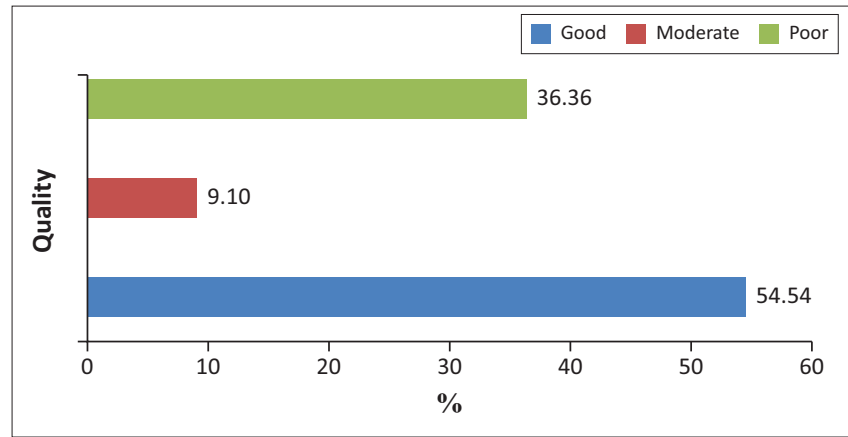

FIGURE 2: Quality of delivered water.

shows that over $35 \%$ residents are still not drinking safe water. According to Mafete (2005:45), the delivery of safe and sufficient water remains a goal of the local sphere of government in the 21st century. It is important that MLM cover the outstanding areas and maintain consistency in the delivery of clean and quality water going forward. Data show that 30 respondents concurred that they had access to quality water, both for domestic consumption and drinking. Despite that, a significant number of respondents (25) indicated that the water was poor or moderate, in terms of its quality.

\section{Monitoring of water treatment and delivery}

Respondents were asked whether there is monitoring of water provision in the MLM. This was one of the study's objectives. Data were collected through interview with responsible officials from MLM and Bojanala Platinum District Municipality, as well as other respondents pooled from locally based civic organisations. In all interviews, respondents agreed that there are no proper and effective monitoring mechanisms to monitor water provisions. Respondents' answers are corroborated by one MLM official responsible for water provision, who said:

'The surge in monitoring and evaluation practices in the public sector has not spared municipalities in their quest to deliver public goods and services in a sustainable way to their residents. In so doing, all components of the broader service delivery programmes could be improved by regular monitoring, to check compliance and progress. Madibeng Local Municipality's water provision apparatus and infrastructure needs continuous monitoring, e.g. monitoring of water treatment.' (Female Junior Official, MLM Water Unit)

Another official who is a manager in the MLM unit responsible for water added that:

'The municipality is currently trapped in a web of obstacles, such as political interference, critical skills shortage, and the absence of projects monitoring ... all of which need to be addressed in the near future.' (Participant 3, Manager, MLM Water Unit)

Respondent 1 touched on the issue in the following excerpt:

'The Madibeng municipality is clouded in a lot of political interference in the administrative functions. As a result, we have not been able to effectively deliver services. Those with the political muscle view themselves as the most powerful and therefore want to influence all aspects, including task that we, the administrative arm of the municipality, are hire to do. Due to them having this imaginary and quite powerful influence, we are left disempowered, and it is not only our work that suffers, but public service delivery. We, for example, rank water access and quality as being a top priority, but some local government politicians might be obsessed with the surfacing of roads, since they perceive it to be a way of wooing votes, be it in local government or general elections, for their party.' (Respondent 1, Senior District Official)

This view from a middle-level municipal official is indicative of the faltering relations in the municipality. Such a situation resembles most modern-day politically charged workplaces, where professionals, like municipal or supply chain managers, have their decisions and powers vetoed by mayors, who prioritise political point-scoring over achieving the objectives of local government, as set out in Section 152 of the Constitution of the Republic of South Africa (1996). This predicament continues to haunt municipalities, who have to grapple with otherwise solvable conflicts, which hugely affect quality water services provision.

Therefore, as argued throughout this article, and based on the Constitution (1996) and other pieces of legislation or policies, water is a basic human right, which enables the subsequent enjoyment of other related and auxiliary rights. For instance, the right to a safe environment and human dignity will not be attainable in the absence of the 'world's most precious liquid', water. In the same vein, water should be treated as a broad and hugely significant right in modern society.

\section{Conclusion and recommendations}

The following recommendations seek to improve the quality water provision in MLM, and they are based on the findings in the previous section.

- Human Capital Training and Development: South Africa has, over the years, grappled with the scarcity of critical and other skills that could give effect to an expedited socio-economic and community development. As the literature and data analysis reveal, water treatment, harvesting and provision to the communities in MLM have been, inevitably, negatively affected by these human capital shortfalls. In that regard, the study recommends an intensive training and development intervention for public-sector human capital provisioning. The State should lead by incentivising training and development initiatives aimed at building enough stock of critical skills for the provision of quality water and other essential services. This correlates with what Mpofu and Hlatywayo (2015:135) have argued, that is, that training and development of staff is essential for building capacity for basic service delivery by municipalities.

- Harmonious Intergovernmental Cooperation: According to Malan (2008:83), an effective system of intergovernmental relations is critical to the success of public service delivery. In the context of the study, the ugly squabbles between officials of MLM and Bojanala 
Platinum District Municipality are holding back progress made in community development and, hence, should be amicably resolved. The intergovernmental spirit of 'oneness in separation' should be duly promoted, in line with constitutional requirements for cooperative government, as stipulated in Sections 40 and 41 of the Constitution of the Republic of South Africa (1996). Therefore, as Shopola (2019) contends, district and local municipalities have to find common ground and forge cooperative and amicable relations, so as to expedite action on service delivery and quality water provision.

In conclusion, there is no doubt that South Africa prides itself into having one of the most advanced constitutions in the world, and this is because of its stance on fundamental human rights. One of the rights that are promoted includes the right to access clean and quality water. In endorsing this right in 2010, the United Nations underscored that the right to water is quite significant in the advancement of living standards (UN 2010). As demonstrated throughout the article, South African municipalities have been tasked with providing basic services like water to their communities. Regrettably, like other municipalities, MLM has been confronted with various challenges that continue to affect its ability to deliver quality water. As indicated earlier on, it is these challenges which have affected the zeal to improve community access to water, together with the need for quality drinkable water provision.

The article has examined and analysed challenges of water provision in MLM using a mixed-methods approach. Therefore, key findings include political tensions and skills scarcity, which can be resolved through various mechanisms such as harmonious district-local intergovernmental relations, and human capital training and development as discussed in the closing section of this article. In closing, the study values the right to water, sanitation and healthy living conditions as a tenet of decent living standards. Public entities need to ensure that people-centred strategies are used to deliver services and desist from egoistic behaviours which are derailing community development. Water is precious to life, and its absence affects nourishment and sanitation, which can be detrimental to local communities even to an extent of bringing catastrophic eventualities like disease outbreak.

\section{Acknowledgements}

Tshwane University of Technology, Department of Public Management.

\section{Competing interests}

The authors have declared that no competing interest exist.

\section{Author's contributions}

This work was extracted from Josephine E. Ranngu's Master's dissertation, which she wrote under the supervision of Dr Ricky M Mukonza. All authors contributed equally to this work.

\section{Ethical consideration}

This work was approved by the Faculty of Humanities Ethics Committee at Tswane University of Technology on 18 May 2012. Ethical clearance number: FCRE/PM/STD/2012/12.

\section{Funding information}

This work received no specific grant from any funding agency in public, commercial or not-for-profit sectors.

\section{Data availability statement}

Data sharing is not applicable to this article as no new data were created or analysed in this study.

\section{Disclaimer}

The views and opinions expressed in this article are those of the authors and do not necessarily reflect the official policy or position of any affiliated agency of the authors.

\section{References}

Akinboade, O.A., Mokwena, M.P. \& Kinfack, E.C., 2014, 'Protesting for improved public service delivery in South Africa's Sedibeng District', Social Indicators Research 119(1), 1-23.

Bless, C., Higson-Smith, C. \& Kagee, A., 2006, Fundamentals of social research methods: An African perspective, Juta, Kenwyn.

Bond, P., 2014, South Africa's resource curses and growing social resistance, viewed 10 July 2020, from https://monthlyreview.org/2014/04/01/south-africasresource-curses-growing-social-resistance/.

Brillantes, A.B. \& Cuachon, N.G., 2002, Decentralization: An overview. Sourcebook on decentralisation in Asia, Asian Resource Centre for decentralization, CLRG working papers series 2002/02, University of the Philippines, Quezon City, pp. 1-12.

Brynard, D.J., Harnekom, S.X. \& Brynard, P.A., 2014, Introduction to Research, 3rd edn., Van Schaik, Pretoria.

City Population, 2017, The population of the Let/habile community residents, viewed 22 January 2019, from http://www.citypopulation.de/php/southafrica-northwest. php?cityid $=661024001$.

Creswell, J.W. \& Plano Clark, V.L., 2011, Designing and conducting mixed methods research, 2 nd edn., Sage, Thousand Oaks, CA.

Govender, E.C., 2016, 'An examination of Rand Water's skills development for the production of quality drinking water locally', PhD thesis, University of the Witwatersrand, Johannesburg.

Haigh, E.H., Fox, H., Davies-Coleman, H., Hughes, D., Atkinson, D. \& Mccann, M., 2008, The role of local government in integrated water resources management linked to water services delivery, WRC Report No. 1688/1/08, Institution for Water Research, Grahamstown.

Hofmeyr, W., 2012, 'Intergovernmental response to address failing municipal water supply services: A legal perspective', MA dissertation, North-West University, Potchefstroom.

Khalo, T., 2008, 'From a separated to a unified public service: The search for seamless delivery of public services in South Africa', Journal of Public Administration 43(Special issue 1), 214-225.

Khan, A., 2003, 'Water privatization in South Africa: A critique of the application of the neo-liberal policy framework', MA dissertation, University of New Brunswick, Canada.

Kolanisi, U., 2005, 'A South African study of consumers' perception and basic social services: ensuring accountability in household utilisation of rural water service', MA dissertation, North-West University, Potchefstroom.

Madi, T.C., 2016, 'Service delivery through deep democratic decentralization.and equitable distribution of water and sanitation services in the Newcastle Local Municipality', MA dissertation, University of the Free State, Bloemfontein.

Mafete, L.F. 2005, 'Investigation into the role of the North-West Water Board in water service delivery management in municipalities: The case of Mafikeng Central District Municipality', MA dissertation, North-West University, Mahikeng.

Makhari, C.L., 2016, 'Assessment of water service delivery in the municipalities of City of Tshwane, City of Cape Town and EThekwini', MA dissertation, University of Western Cape, Cape Town.

Malan, L.P., 2008, 'The impact of intergovernmental relations and co-operative government on good governance in South Africa', African Journal of Public Affairs 2(1), 76-86.

Moeti, K. \& Khalo, T., 2008, 'Privatisation and ensuring accountability in the provision of essential services: The case of water in South Africa', Journal of Public Administration 43(Special issue 1), 219-230. 
Mpofu, M. \& Hlatswayo, C.K., 2015, 'Training and development as a tool for improving basic service delivery; the case of a selected municipality', Journal of Economics, Finance and Administrative Science 20(39), 133-136.

Municipal IQ, 2015, Tackle the root causes to kill off protests, viewed 07 June 2020 from: http://www municipaliq co.za/index php?site page=article. php\&id=83.

Municipalities of South Africa, 2018, The local government municipalities of South Africa', viewed 10 March 2018, from https://municipalities.co.za/

Nealer, E. \& Raga, K., 2007, 'Nature and extent of local governance in South Africa', Journal of Public Administration 42(5), 171-182.

Nsingo, S.A.M. \& Kuye, J.O., 2005, 'Democratic participation for service delivery in local government in Zimbabwe: Humanising structural configurations and legal provisions', Journal of Public Administration 40(4), 744-760.

Republic of South Africa (RSA), 1996, Constitution of the Republic of South Africa, Government Printer, Pretoria.

Republic of South Africa (RSA), 1998a, White paper on local government, Department of Provincial and Local Government, Pretoria.
Rogerson, C.M., 2010, 'Local economic development in South Africa: Strategic challenges', Development Southern Africa 27(4), 481-495. https://doi.org/10.108 0/0376835X.2010.508580

Rogerson, C., 2018, Local economic development in the changing world: The experience of Southern Africa, Routledge, London.

Shopola, M.A., 2019, 'An empirical analysis of intra-local governmental relations in Mopani District Municipality', Unpublished Masters dissertation, Tshwane University of Technology, Pretoria.

Shopola, M.A. \& Mukonza, R.M., 2020, Inter-governmental relations in Mopan District Municipality, South Africa - An empirical review, African Renaissance 17(3), 149-165.

South African Human Rights Commission (SAHRC), 2016, Madibeng water issues goes to court, viewed 20 March 2018, from https://www.sahrc.org.za/index.php/sahrcmedia/news/item/437-water-issue-to-go-to-court

United Nations (UN), 2010, United Nations General Assembly No. 64/292: The Human Right to Water and Sanitation, United Nations, Geneva. 